\title{
A CRITICAL REVIEW OF JOHN LOCKE'S DENIAL OF INNATISM
}

\section{MALACHY IFEANYI OKAFOR ${ }^{1}$ \& IGNATIUS NNAEMEKA ONWUATUEGWU PHD ${ }^{2}$}

\author{
${ }^{1}$ Pope John Paul II Major Seminary Okpuno, Nigeria \\ ${ }^{2}$ Philosophy Department, Faculty of Arts, Nnamdi Azikiwe University Awka, Nigeria
}

\begin{abstract}
In the philosophical circle, philosophers attempt with utmost curiosity to study the most fundamental structures of man's total experience in order to arrive at beliefs that are as conceptually clear, experientially confirmed and rationally coherent as possible. This will bring stability and fluency in thinking amidst the philosophy expectancy of human thought. In this research paper; A Critique of John Locke denial of Innatism, the researchers' aim is to critically examine with every amount of thoroughness, John Locke's denial of innate idea. As an empiricist, he holds that all knowledge is acquired through experience and never innate. He also assert that, "human brain is tabula rasa," that is to say, no idea in the brain from birth, but, all is acquired through experience. This position of John Locke brought about disagreement between two schools of thought, the empiricist and rationalist. The empiricist is of the view that all knowledge is acquired through experience while the rationalist is of the view that knowledge is innate. The essay of John Locke triggered the expansion of the chasm between the two camps; denying the acquisition of knowledge through innate ideas, he resorted to doctrine of acquiring of all knowledge through experience. With Locke's stand on empiricism, the question becomes; If Locke holds that all knowledge can be attained through experience, how can some meta-empirical realities be explained? There are some characters exhibited by children before the age of cognition. How can such characters be explained empirically, given that they have not yet attained the age of cognition? These are the questions that this work will seeks to $x-$ ray. And as well taking into cognizance of the fact that all knowledge does not come either from experience alone or originally from the mind alone but the two, reason and experience are needed for the attainment of truth. The expository and critical approach, therefore, should be applied by the researchers to achieve the aim of the study.

KEYWORDS: Philosophy, Researchers \& Knowledge
\end{abstract}

Received: Aug 04, 2020; Accepted: Aug 24, 2020; Published: Sep 28, 2020; Paper Id.: IJESRAUG202013

\section{LITERATURE REVIEW}

The theory of knowledge of John Locke was the foundation to his refutation of innate idea. Locke was at beginning convinced that there is no innate idea. For him, therefore, all knowledge is derived from experience. He likens the mind to be like a white paper, void of all characters, without any Ideas. With this foregoing we shall now proceed to examine this position of Locke as reviewed by some selected authors.

The first work we shall expose is True Intellectual System of the Universe, 1778, here Cudworth, set himself towards refuting Locke's assertion that there is no innate idea. More still, Ralph brings Locke's position to limelight that, all knowledge is acquired through experience, better still, holds that, demonstration of God existence rested upon the premise that certain principles are innate in the human mind. Furthermore, he contended that the famous empiricist Locke formula that "nothing exists in the intellect which was not first in the senses" (Cudworth; 
1678). On this ground, Ralph says that, "if knowledge consists solely of information supplied to the mind by objects external to it, the external world existed before there was knowledge" (Cudworth; 1678). Above all, he insists that there is innate idea which is against Locke's claims over the non-existence of innatism.

More so, David Hume makes known the affirmation of Locke on the basis that, "all knowledge is founded on sensory experience (Hume; 2007). Nevertheless, Hume reveals the objects of mind, of Locke, to be perception. Thus, Hume further makes known the division of Locke's perceptions, which is impressions, and ideas. He goes on to explain the assertion of Locke, that all the materials of thinking come from experience, from our outward or inward impressions. This entails that any idea one employs must be copies of earlier impressions (Hume; 2007).

Further still, Russell brings in Locke's view on the rejection of innate idea and the affirmation that 'our ideas are derived from two sources: (a) sensation and (b) perception of the operation of our own mind, which may be called internal sense (Russell; 1961). More so, he exposes Locke's thought all the more that, "since we can only think by means of ideas, and since all ideas come from experience, it is an evident that none of our knowledge can antedate experience" (Russell; 1961). Furthermore, Russell in favour of Locke says, that perception is 'the first step and degree towards knowledge, and inlet of all the material of it' (Russell; 1961).

Nevertheless, Stumph, in Philosophy History and Problems (1971), obviously divulges Locke's position that, "if Locke is going to say that all ideas comes from experience, he must reject the theory of innateness". Further still, he points out Locke's outlook that "it is an established opinion among some men that there are in the understanding certain innate principles... stamped upon the mind of man, which the soul received in its very first beginning, and bring into the world with it" (Stumpf; 1971). Moreover, Stumph gives more light to Locke's assertion that, "not only that Locke rejected innate ideas as not true, but he considers the doctrine a dangerous tool in the hands of those that misuse it" (Stumpf; 1971). Furthermore, Stumph exposes Locke's thought the more, on the note that, "if a skillful ruler could convince people that certain principle are innate, this could take them off from the use of their own reason and judgment, and put them on the believing and taking them upon trust without further explanation. And, in this blind credulity, they might be more easily governed. But there were those whose interest in the theory of innate idea was not so malignant" (Stumpf; 1971).

Moreover, Frost, in Basic Teaching Of great Philosophers (1989), uncovered the position of John Locke against innate idea. Furthermore, he tells us that, "Locke made the study of knowing his chief occupation". Again, Justin exposes the conclusion drawn by Locke, "that all ideas come to the individual through sense experience and that, the mind is a blank tablet only with the power to assimilate or organize impression" (Frost; 1989). Notwithstanding, Justin explains that as the power of assimilation contact with environment stimulates with the sense and cause impression, the mind receives and organize these into idea and concept. Thus he maintains that there is no innate idea in the mind; all idea comes from without (Frost; 1989).

As a matter of fact, Omoregbe, in his work, Knowing Philosophy (1990) disagrees with Locke's rejection of the theory of innate idea. Though Omoregbe, discloses the position of Locke, that there is no such idea in man's mind at birth and maintains that all knowledge and all ideas comes from experience. Perhaps, Omoregbe continues with the explanation of Locke's position that, man is not born with any idea; the human mind at birth is completely blank. On the other hand, Omoregbe in his Knowing Philosophy discards Locke's above initial view. Still more, he believes that the process of learning begins with the basic idea known as innate idea. These ideas are in our mind at birth, we don't need to learn them before we know them; they erupt as soon as we reach the age of reasoning (Omoregbe; 2005). 
However, Omoregbe in his book: A Simplified History of Western Philosophy, 1991, he unfolds to us Locke's rejection of the theory of innate knowledge or theory of innate ideas. To give more clarity to Locke's idea, Omoregbe opens up Locke's position that, all ideas come from sense experience; for him, there is nothing like innate idea. More still, he gives in details Locke's assertion that; man is not born with any ideas in the mind. Perhaps, Omoregbe brings to light Locke's argument that if these ideas were really innate, they would be known by both children and idiot because they have mind. Meanwhile, Omoregbe, refuted this assertion as stated above. He supports and presented innate idea, which holds that man is born with certain ideas in his mind and that as soon as he reaches the age of reason he comes to know these ideas spontaneously without having lean them explicitly. More still, it is the primary principle of reason(Omoregbe; 1991).

Still more, Gaarder, in his book: Sophie's World: A Novel About the History of Philosophy,1995, makes known to us John Locke's position against innate idea, on the claims that all our thought and ideas are acquired through the senses and never innate in human mind. Furthermore, Gaarder, tells us in detail about Locke's assertion that, before we perceive anything, the mind is a tabula rasa or an empty slate. Again, before we sense anything, then, the mind is as bare and empty as a blackboard before the teacher arrives in the classroom, Further still, Justin compare the mind as an unfurnished room, but then, we begin to sense things. We see the world around us, we taste, feel smell and hear. On this ground, he holds firm that there was no innate idea (Gaarder; 1995).

Nevertheless, W.F. Lawhead in his book: Voyage of Discovery: a Historical Introduction to Philosophy, 2002, enlightens us on the position of Locke, that all knowledge is acquired through sense experience, perhaps, no knowledge is innate or in the mind at birth. More so, he brings to limelight that Locke employed an under-labourer in clearing the ground a little, and removing some of the rubbish that lies in the way to knowledge which is the doctrine of innate ideas. Further still, in revealing Locke, Lawhead tells us to know that, some kinds of ideas, principle or knowledge are acquired through experience, but are built into the mind(Lawhead; 2002).

Further still, Ezeani, in Fundamental of Philosophy and Logic, 2009, reveals Locke's position that every knowledge proceeds from sensation and reflection. More so, he brings to limelight Locke's view that each man's mind is like a 'tabula rasa'(blank sheet).To this end he asserts that, "if the mind is to be... white paper, void of all characters, without any idea, how come is it to be furnished?...whence has it all the material of reason and knowledge? I answered in one word, from experience" (Ezeani; 2009). In addition, Ezeani made effort to elucidate Locke's denunciation of innatism - which holds that there is in the understanding of man certain innate principle stamped in the mind of human, which the soul received at its very beginning and brings into the world with it. He depicts Locke's serious objection of innatism, and maintains that no idea can be said to be in the mind which is not yet known through the senses(Ezeani; 2009).

It was Carlin, who in his book: The Empiricist; a Guide for the Perplexed, 2009, explicitly make known Locke's affirmation that, "knowledge is not directly about anything other than our ideas" (Carlin; 2009). Besides, Carlin make public that, for Locke, experience yield ideas (sense data or concept), and the mind have access only to these. Perhaps, Justin, tell us that for Locke, the mind does not directly perceives chair and table, but only the idea of chair and table supplied by the way of mechanistic sensory impact from the actual, mind-independent of chair and table. That is to say, there is no innate idea (Carlin; 2009).

Nonetheless, Anowai(2001) pictures the opinion of Locke that, "when a person is born, he knows nothing, as he goes on in life, experience he has with the five senses writes information on the tablet of his mind". He further acknowledges Locke's insight as a representational view of knowledge. For Locke, Anowai expounds that, "the idea in our 
mind is the representation of the things in the real world" (Anowai;2001). More so, he explicates the position of Locke thus: All knowledge derives from and is based on sense experience. The mind is a 'blank sheet' until sense experience writes upon it. All content of our mind comes ultimately from internal reflection of what is in our minds. Sense experience is made up of sensory experience produced in our mind by things in the external world through the direct and indirect impact upon the sense organ of the bodies. He called this view Representative Theory of Perception (Anowai; 2001).

However, Anaeto (2015) clearly makes known Locke's rejection of the theory of innate ideas, "affirming that all knowledge is acquired through sense experience". Moreover, Anaeto's explanation points towards Locke's position that, there is no innate idea. Furthermore, he explicitly makes known Locke's belief that our idea came from sensation and reflection. However, for Locke, Anaeto further clarifies that, sensation has to do with perception of external object through the senses, which is against the theory of innate idea, while reflection is the activities of the mind on the perception of the senses, thus, given rise to idea in the mind through the reflected objects and never from birth(Anaeto; 2015).

\section{LOCKE AND HIS DENIAL OF INNATISM}

Having seen in the preceding pages what some philosophers and thinkers have said about Locke's denial of innatism, we shall now focus on the exposition of Locke's arguments against innate idea. His arguments are contained in his work entitled An Essay concerning Human Understanding. Locke made his denial of innate ideas under the following, namely (a) No innate speculative principles (b) No innate practical principles, and (c) Other considerations concerning innate principles, both speculative and practical.

\section{DENIAL OF INNATE SPECULATIVE PRINCIPLES}

Locke's denial of innate speculative principles was discussed in his Essay concerning Human Understanding, under the theme; No Innate Speculative Principles. Here, Locke agrees to the fact that there is belief in the presence of some ideas in the human mind before its existence in the world. In his words:

It is an established opinion among some men, that there are in the understanding certain innate principle, some primary notions, characters as it were stamped upon the mind of man, which the soul receives in its very first being, and brings into the world with it(Locke).

Thus for him, it is universally agreed upon by all mankind: that there are certain principles which the souls of men receive in their first beings, and brings into world with them. Nonetheless, Locke suggests that, even though there is, it would not prove them innate. He examined the principle of identity and non-contradiction. For Locke, it is not everybody that knows of the principles that what is, and it is impossible for the same thing to be and not to be. However, Locke denies the existence of such principle being imprinted on the mind since childhood and idiots are ignorant of such. More still, he says, not on the mind naturally imprinted, because not known to children, idiots etc. For, first it is evident, that all children and idiots have not the least apprehension or thought of them(Locke).

Locke goes further to say that, it is a contradiction to say that there are present in the mind some principles and yet children and idiot do not perceive or understand it. In his exact words: For to imprint anything on the mind without the mind's perceiving it, seems to me hardly intelligible. If therefore children and idiots have souls, have minds, with those impressions upon them, they must unavoidably perceive them, necessarily know, and assent to these truths(Locke). 
From the forgoing, Locke then concludes that such principles cannot be innate, since children and idiots cannot know them. Considering all these facts, Locke denies such principles from being innate if at all there is, it is nothing, since unknown to all. Furthermore, Locke brings to light the fact that these principles, according to people, are known once one comes of age. Locke says that to accept this could imply two things: either that these principles are known by them once they come to the age of reason or that the use of reason can assist them to discover these principles. To the idea that the use of reason helps men to discover these principles, Locke says: "That whatever truths reason can certainly discover to us, and make us firmly consent to, those are all naturally imprinted on the mind" (Locke). Admitting to the fact that some knowledge are got upon the first proposed while some needs reasoning, Locke affirms that if some are gotten immediately and some after reasoning, then it is wrong to say that the mind has knowledge of all things before its earthly existence. He goes further to say that reasoning is the faculty of deducing unknown truths from principles or propositions that are already known. More still, he says that since this reasoning is search and requires pains and application, then knowledge got through such process should not be considered naturally impressed. Thus, he contends: For all reasoning is search and casting about, and requires pains and application. And how can it be with any tolerable sense be supposed, that what was imprinted by nature, as the foundation and guide of our reason, should need the use of reason to discover it?(Locke).

On this ground, Locke holds that any knowledge which is attained through reasoning, search and application is not to be viewed as innate. Locke believes that reason has nothing to do with the procuring of consent to those maxims since assenting to maxims does not lie on the faculty of reasoning. He then concludes: If by saying that "men know and assent to them, when they come to the use of reason", be meant, that the use of reason assists us in the knowledge of these maxims, it is utterly false; and were it true would prove them not to be innate(Locke).

More so, Locke accepted the coming to the use of reason, but for him, it is falsely assigned as time of discovery. For him, men come to the use of reason before they get the knowledge of those general truths, but not the time to discover. Locke, continued by saying that such proposition is not framed in the mind even after they have come to the use of reason. He argues that, people supposed those propositions to be innate but are merely discoveries made and brought into the mind in the same way others (knowledge) were through experience.

\section{DENIAL OF INNATE PRACTICAL PRINCIPLES}

Here, Locke accepted the truthfulness of moral principles even though he rejected that they are innate. To this end, he says: "But the ignorance where in many men are of them, and the slowness of ascent where with others receive them, are manifest proofs that they are not innate, and such as offer themselves to their views without searching” (Locke).

Locke believes that there is no practical truth to say that it is universally received innate without doubt or question. For Locke, "the general principle of justice and keeping contracts is that which most men seem to agree in(Locke; 1982)."

Locke observes that, though men deny innate idea in their practice, yet they admit them in their thought. To this end, he maintains, "I have always thought the actions of men the best interpreters of their thoughts that most men practice and others open profession(Locke; 1982)." More so, he asserts then, that: "It is very strange and unreasonable to suppose an innate practical principle that terminates in contemplation" (Locke; 1982).

Going further, Locke submits that practical principles derived from nature are there for operation and must produce consistency of action, not merely speculative assent to their truth, or else they are in vain distinguished from speculative maxims. 
For him, nature has natural tendencies like happiness and misery in man, but these practical principles are not innate in man. However, they are there, always lying front to be found. Therefore, for Locke, if these principles are really to be seen as innate, it must be apprehended consciously from the beginning of life and hence would be undesirable.

More still, Locke brings to limelight that no man is born with any innate principle in the mind because for it to be innate, it needs no reason to justify or to prove it since it is supposed to be self-evident. Any innate idea carries its own light and evidence with it and, therefore, it needs no other proof. Hence, Locke says, "he that understands the terms assents to it for its own sake or else nothing will ever be able to prevail with him to do it" (Locke; 1982).

Further still, Locke, maintain that men do not always keep their words; for him, most actions of man tend towards the opposite of what the rule of virtue, which they claim to hold. Thus, he avows: For, if we will not in civility allow too much sincerity to the profession of most men, but think their actions to be the interpreters of their thoughts, we shall find that they have no such internal veneration for these rules, nor so full a persuasion of their certainty and obligation(Locke; 1982).

He means here that men put up with the rule of virtue only for civility sake and not because they regard it with honour. Locke highlights that men have contrary practical principles. This would result to relativism since what is practiced in a given society varies with respect to that practiced in another. He equally criticized the idea of innate ideas on the ground that those ideas are not known. Previously, Locke makes it clear that it would be difficult to find moral principle, which is general to all men. Rather, he decided to deal with the one that is most general among men. He maintains that even at his point of criticizing innate ideas, advocates of these innate ideas have not said what they are. Besides saying what they are, he maintains that if it were to be innate, there would not be need to teach it to anybody. As a reason to show why these principles need not be thought, he says:

Did men find such innate propositions stamped on their minds, they would easily be able to distinguish them from other truths, that they afterwards learned and deduced from them; and there would be nothing more easily than to know what and how many they were(Locke; 1982).

Therefore, nobody is to be blamed if he refuses to accept the notion of innate ideas since the proponents tell neither what they are nor how many they are.

Moral principles, for Locke, are taught. These moral principles come from God or through the mouth of other human beings. Moreover, if moral principles are engraved in the mind and after all were found out that they were initially known after they have been taught on the ground that they are not very clear, then Locke contends that it is "scarcely possible that God should engrave principles in words of uncertain meaning” (Locke; 1982).

Therefore, if it is established that since God cannot engrave what cannot be understood, and man cannot come to learn of it, unless by teaching the moral principles, then they are not innate. Hence, he concludes:

Yet after all, universal consent (were there any in moral principles) to truths, the knowledge whereof may be attained otherwise, would scarce prove them to be innate; which is all I contend for(Locke; 1982).

\section{OTHER CONSIDERATION ON INNATE PRINCIPLES}

From the different ideas argued on in the previous chapters, Locke wishes to establish after all that there are no innate ideas. Here, he tries to create and bring into conclusion the non-existence of innate ideas. This is his concern here. Since Locke 
has tried to establish the absence of innate ideas, he believes that principles can come from nowhere except from ideas. In addition, since there are no innate ideas, there cannot be innate principle or else, it would be meaningless. According to him, since the ideas which made up those truths were not, it was impossible that the propositions made up of them, should be innate, or our knowledge of them be born within us. If this is so, what is it, then he concludes: "For if the ideas be not innate, there was a time when the mind was without those principles; then they will not be innate but be derived from some other original" (Locke; 1982).

For him neither innate ideas nor principle exist at all. On the side of children who at birth can display signs of hunger, thirst, warmth and pain. Locke believes that these signs far from being innate came from their experience of them in the womb. Thus, he propagates that experience alone provides children with these ideas.

Coming to the question of the mathematical whole and part, he did not give a definite answer. He immediately related them to extension and number to which they belong and of which alone whole and part are relations. Therefore, if whole and part are innate ideas, extension and number must also definitely be. In addition, it is not possible to have the idea of relation as innate ideas if the thing to which the relation belongs is absent. He thus concludes by saying: Now, whether the minds of men have naturally imprinted on them the ideas of extension and number, I leave to be considered by these who are the patrons of innate principles(Locke; 1982). Locke tries to discredit the idea of God being innate. On the argument that the idea of worship leads to the idea of God, he holds that the idea of worship is not innate because the idea of God go before the idea of worship. He sees it as a duty of which people are learned of to carry out to God. Children do not know of such duty for it will be silly to say so. Since the idea of worship is learned, then children will be furnished with it or else: There cannot be anything more ridiculous than to say that children have this practical principle innate, 'that God is to be worshipped' and yet that they know not what that worship of God is, which is their duty(Locke; 1982).

Locke countered the idea of God being innate. That people down to many generations know of it, is not because they are innate, but because the name ascribed to God is suitable to men. Those names as he listed them are superior, powerful, wise, an invisible being. Such suitable notions cannot but be always a topic discussed amongst men that warrants them to speak of it at all times. But, it cannot be innate if different people especially the unthinking sect have varied or unsteady opinion of that same God. He tried to put side by side the idea of God and fire. He cited an instance with a colony of young children placed on an Island where no fire was. They certainly according to him will have no notion of fire, because they were segregated from where it could be found. Then people cannot know of God if it is not discussed within their locality. The idea of God comes to people only through information; as he says: Perhaps too their apprehension would be as far removed from any name or notion of a God, until someone among them had employed his thought to inquire into the constitution and causes of things, which would easily lead them to the notion of a God(Locke; 1982). If this idea reaches them and they reason it to make sense, not only will they welcome it, but also will propagate it continuously among men.

Locke sees all created things, including innate ideas and principles as a pointer to God. Not only that God is widely discussed among men, but also the notion of God is seen to be the most natural discovery of human reason. Locke sees it that if that which is the most natural discovery of human reason is not innate, nothing can. The existence of creatures is a pointer to a God, who created them. Thus, if there are creatures, then it implies the existence of a creator who created them, hence God. If the notion of creatures implying a creator is considered innate, this should not establish their maker innate for: 
Since if God hath set any impression, any character on the understanding of men, it is most unreasonable to expect it should have been some clear and uniform idea of Himself, as far as our weak capacities were capable to receive so in comprehensible and infinite an object(Locke; 1982).

Locke believes it is purposeless for certain characters to be inscribed on man's mind with the finger of God without them being clearer and more useful. He is of the opinion that if God were to imprint those ideas on the mind, it cannot but be clearer and more useful than others acquired are.

Thus for him, the fact that it is not clear and that everyone would not find it true in himself, then it cannot be innate. Locke says that it is on this ground that he goes into inquiry to the nature and source of human knowledge. And therefore, he is not going into this inquiry to win fame from men; rather, he tries to inquire for truth. For him, though he gathered these opinions, he will have to subject them to scrutiny on the screen of truth. He denies innate ideas and sees it as a lazy man's excuse. Thus, he insists that men must think and know for themselves, for that which one knows is for one gold and that is what one really has.

\section{CONCLUSIONS}

In solution to the real source of human knowledge, Locke, in his Essay Concerning Human Understanding, tries to deny the theory of innatism, he considers experience to be the ultimate source of human knowledge. However, he fails to consider other avenue through which knowledge is acquired outside experience.

Furthermore, scientific result alongside with discoveries has evidence that in sense-perception; a lot of information is lost about the truth of the object been observed. If this is the case then knowledge through experience cannot be credited as an ultimate source of knowledge.

However, the critical problem concerning sense-perception is: what kind of reality belong to the object perceived and to the organ that perceives them. Better still, the question above brings in some difficulties in determining the exact connection between the perceiver and the object perceived. Again, for Locke, in his philosophical position, there is no need to talk about reason as a source of knowledge. However, the rationalist such as Leibniz believes that knowledge could be gotten outside experience through reason(Leibniz).

Furthermore, Locke contributed immensely to the advancement of modern philosophy and philosophy at large, in the sense that experience provides no doubt to some knowledge of objects. But does not account for all human knowledge.

However, while it could be admitted that some degree of knowledge could be acquired both by experience and reason. Yet none in itself is so sufficient to be the ultimate source of human knowledge. Thus, given the insufficiencies in both experience and reason as the ultimate source of human knowledge, Kant tries to strike a balance with his Mediation between rationalists and empiricists. Here, he holds that rationalists and empiricists are both partially correct in their view that human knowledge comes from reason and the senses respectively. The raw materials of knowledge are received by us in the form of sensation which we get from an outside source, hence in sensation we are passive. On the other hand, we are active in thought since thought consists of a spontaneous operation of the mind on the materials sensation feeds the mind with(Kant; 1998). From this, it is clear that knowledge is neither the effort of the subject nor of the object; true knowledge cannot be gained either rationally alone or empirically alone, but it can be gained by the synthesis of the continued action of the subject and the object, sensation and thought. More so, Lawhead commenting on Kant's mediation says "For sense data to be experienced as object by us, the mind must impose a certain rational structure on them"(Lawhead; 2002). When 
the subject provides the form and the object provides the matter, knowledge is gained, and this knowledge becomes the result of a priori element, (the subject) and of a synthetic element (the object).

\section{REFERENCES}

1. Anaeto, B. C. (2015) in West African Journal of Philosophical Studies; Implications of Lockean Empiricists On Education of Children, volume 17, p. 22.

2. Anowai, E. C. (2001) Philosophy: A More Historical Approach, 1st edition, FabAnieh Nig. Ltd, Awka.

3. BAMANE, SUJATA. "STUDY OF 'BRAIN IN VAT'OR 'BRAIN IN FLUID'? SCENARIO IN NAYOMI MUNAWEERA'S WHAT LIES BETWEEN US: A DIFFERENT PERSPECTIVE." International Journal of English And Literature (IJEL) 9.5, Oct 2019, $17-26$

4. Carlin, L. (2009) The Empiricist; A Guide for the Perplexed, New York, London.

5. Cudworth, R. (1678) True Intellectual System of the Universe.

6. Ezeani, G. I. (2009) Fundamental of Philosophy and Logic, 1st edition, J. Jacob's Classic Publisher Ltd, Enugu.

7. Frost, S. E. (1989) Basic Teaching of great Philosophers, 1st edition, Anchor Books Random House Inc; U. S. A.

8. Gaarder, J. (1995) Sophie's World: A Novel About the History of Philosophy, trans. P. Moller, Harper Collins Ltd, Canada.

9. Hume, D. (2007) Concerning Human Understanding, Edited, P. Milican, Oxford University Press, U. S. A.

10. Kant, I. (1998) Critique of Pure Reason, trans. Paul Guyer and Allen Wood, Cambridge University Press, Cambridge.

11. Lawhead, W. F. (2002) The Voyage of Discovery: A Historical Introduction to Philosophy, Wadsworth Group, U. S. A.

12. Leibniz, G. Discourse on Metepysics and Related Writings, edited and translated by R. N. D. Martin and Stuart.

13. Locke, J. An Essay Concerning Human Understanding, in http://www.ilt.columbia.edu/publication/Locke-understanding.html, Bk.1, Chp 1, Par 1.

14. Locke, J. (1982) An Essay Concerning Human Understanding, Quoted in Great books of the Western World, ed. R. M. Hutchins, University of Chicago Vol. 35, Encyclopedia Britannica, Inc, London.

15. Omoregbe, J. (1991) A Simplified History of Western Philosophy, 2nd edition, Ikorodu road Maryland, Joja Press Ltd, Lagos.

16. Omoregbe, J. (2005) Knowing Philosophy, 2nd edition, Ikorodu road Maryland, Joja Press Ltd, Lagos.

17. Russell, B. (1961) in History of Western Philosophy, 2nd edition, Gorge \& Unwin Ltd, London.

18. Stumpf, S. E. (1971) Philosophy: History and Problem, 6th edition. 
